\title{
Study on Leaching of High-Magnesium Laterite
}

\author{
Lifang Kuang ${ }^{1, a}$, Junyue $\operatorname{Tan}^{1, b}$ and Kui Liu, ${ }^{1, c^{*}}$ \\ ${ }^{1}$ School of Chemistry and Pharmaceutical Science, Guangxi Normal University, Guilin 541004, \\ China \\ ahua163@126.com, wwmm@126.com, 'lku009@163.com
}

\begin{abstract}
Keywords: acidity; magnesium concentration; iron concentration; solution $\mathrm{pH}$
Abstract. The leaching of laterite containing high-magnesium content was investigated in this study. The results show that the acidity of the leach liquors from high pressure leaching of laterite containing high iron content is high enough for the leaching of high-magnesium laterite. After leaching at $70^{\circ} \mathrm{C}, 60 \mathrm{~min}$ and solid/liquor ratio of $10 \mathrm{~g}$ ore $/ \mathrm{L}$ leaching agent, the mineral containing high magnesium content was completely dissolved, and the iron minerals were essentially undissolved. The solution $\mathrm{pH}$ increased to 2.5 or above, which was suitable for the subsequent iron removal process.
\end{abstract}

\section{Introduction}

The leaching of laterite containing high magnesium content is always conducted at atmospheric pressure, which needs large amounts of acid, such as sulfuric acid, hydrochloric acid or nitric acid $[1,2]$. The leaching of laterite containing high iron content is always conducted at high pressure, which produces leach liquors with a certain amount of residual acid [3-5]. Additionally, the iron in the leach liquors from pressure leaching process has a relatively low concentration, usually within $1-2 \mathrm{~g} / \mathrm{L}$. Thus, the goethite process is utilized to remove iron from leach liquors of pressure leaching of laterite. The goethite process usually requires that not only the $\mathrm{Fe}^{3+}$ concentration in the solutions is below $1-2 \mathrm{~g} / \mathrm{L}$, but also the solution $\mathrm{pH}$ is greater than 2[6-8]. However, the $\mathrm{pH}$ of leach liquors from pressure leaching of laterite is about 1 or so. This restricts the goethite process to be used for iron removal from leach liquors of pressure leaching of laterite.

In this study, the leaching of laterite containing high magnesium content was investigated, using the leach liquors of pressure leaching of laterite containing high iron content as the leaching agent. This can reduce the acid consumption of high-magnesium laterite and increase the $\mathrm{pH}$ of leaching agent to meet the requirement of goethite process. The leaching conditions were studied. The dissolution of minerals with high-magnesium content and the variation of solution $\mathrm{pH}$ were discussed.

\section{Experimental}

Materials. The Ore samples containing high magnesium content were grey rock shivers. Ore samples were ground in a discal crusher for a few minutes to mill the rock shivers, followed by being screened to below $165 \mu \mathrm{m}$. Then the ore samples were dried overnight in an oven at $100^{\circ} \mathrm{C}$. The chemical analysis of the ore samples is shown in Table 1. The magnesium content was about $24 \mathrm{wt} . \%$ while the iron content was only $4 \mathrm{wt} . \%$, corresponding to the characteristics of high-magnesium laterite. Mineralogical investigation results are shown in Table 2, which shows that the ore samples consist mainly of serpentine, with minor hematite and traces of magnetite and chromite.

Table 1 Elemental analysis of the ore samples (wt.\%)

\begin{tabular}{llllllll}
\hline $\mathrm{Ni}$ & $\mathrm{Co}$ & $\mathrm{Mg}$ & $\mathrm{Fe}$ & $\mathrm{Al}$ & $\mathrm{Cr}$ & $\mathrm{Mn}$ & $\mathrm{Si}$ \\
\hline 0.9 & 0.09 & 23.5 & 4.05 & 0.57 & 0.13 & 0.05 & 16.8 \\
\hline
\end{tabular}


Table 2 Mineral composition of the ore samples(wt.\%)

\begin{tabular}{llll}
\hline serpentine & magnetite & hematite & chromite \\
\hline 86 & trace & 5 & trace \\
\hline
\end{tabular}

The leaching agent was prepared by dissolving cobalt sulfate, nickel sulfate, magnesium sulfate, ferric sulfate, ferrous sulfate and aluminum sulfate (analytical grade) with distilled water, with $\mathrm{Ni}^{2+}$, $\mathrm{Co}^{2+}, \mathrm{Mg}^{2+}, \mathrm{Al}^{3+}$ concentrations of $1.21 \mathrm{~g} / \mathrm{L}, 0.11 \mathrm{~g} / \mathrm{L}, 0.95 \mathrm{~g} / \mathrm{L}, 0.14 \mathrm{~g} / \mathrm{L}$ and $\mathrm{Fe}^{2+}$ 和 $\mathrm{Fe}^{3+}$ concentration of $0.93 \mathrm{~g} / \mathrm{L}$ and $1.91 \mathrm{~g} / \mathrm{L}$. The concentrations of metal ions were similar to those in the leach liquors of pressure leaching of laterite. The solution $\mathrm{pH}$ was adjusted to 1.1 using the dilute sulfuric acid.

Methods. Leaching experiments were carried out in a 500ml Erlenmeyer flask. A mixture of the ore sample and the leaching agent were placed in the Erlenmeyer flask. The Erlenmeyer flask was placed in a magnetic stirrer, heated to the desired temperature, and then leached for a set time at 450rpm. The slurry was filtered and the leach residues were washed with distilled water and dried for $4 \mathrm{~h}$ at $100^{\circ} \mathrm{C}$.

The filtrate was analyzed for nickel, cobalt, magnesium, aluminum by a iCAP 6300 inductively coupled plasma-atomic emission spectrometer. The $\mathrm{Fe}^{2+}$ and $\mathrm{Fe}^{3+}$ concentrations in the filtrate were determined by standard potassium dichromate titration. The solution $\mathrm{pH}$ was measured using a $\mathrm{pH}$ meter (PHS-3E, Shanghai INESA Scientific Instrument Co., Ltd., China).

Some leach residues were analyzed using a D/max $2550 \mathrm{X}$-ray diffractometer (XRD) with $\mathrm{Cu} \mathrm{K \alpha}$ radiation between $10^{\circ}$ to $80^{\circ}(2 \theta)$.

Results and discussion. It can be seen from Table 3 that the solution acidity decreases and solution $\mathrm{pH}$ increases with the increase of leaching temperature. Increasing leaching temperature to $70^{\circ} \mathrm{C}$, the solution $\mathrm{pH}$ was 2.4 , which was within the $\mathrm{pH}$ range of goethite process. Further increasing leaching temperature to $80^{\circ} \mathrm{C}$, the solution $\mathrm{pH}$ changed little. Additionally, the serpentine was gradually dissolved with the increase of leaching temperature. Serpentine was not present at $70^{\circ} \mathrm{C}$, indicating the complete dissolution. There might be minor serpentine at $60^{\circ} \mathrm{C}$ and its amount might be too low to be detected by XRD, as the solution $\mathrm{pH}$ increased obviously when increasing temperature from $60^{\circ} \mathrm{C}$ to $70^{\circ} \mathrm{C}$. Hematite was present in the leach residues within the temperature range of $60-80^{\circ} \mathrm{C}$, indicating hematite could not be dissolved at temperatures below $80^{\circ} \mathrm{C}$. The undissolved magnetite and chromite might be present in the leach residues, but their amounts were too low to be detected by XRD. There should be silicon oxide in the leach residues. They are not detected by XRD, probably because of their amorphous state.

Table 3 Solution $\mathrm{pH}$ and phases of leach residues under different temperatures ( solid/liquor ratio: $10 \mathrm{~g}$ ore/L leaching agent, $60 \mathrm{~min}$ )

\begin{tabular}{lllllll}
\hline Temperature $\left({ }^{\circ} \mathrm{C}\right)$ & 30 & 40 & 50 & 60 & 70 & 80 \\
\hline $\begin{array}{l}\text { Solution pH after } \\
\text { leaching }\end{array}$ & 1.21 & 1.32 & 1.85 & 1.98 & 2.43 & 2.51 \\
$\begin{array}{l}\text { Phases of leach } \\
\text { residues }\end{array}$ & $\begin{array}{l}\text { serpentine, } \\
\text { hematite }\end{array}$ & $\begin{array}{l}\text { serpentine, } \\
\text { hematite }\end{array}$ & $\begin{array}{l}\text { serpentine, } \\
\text { hematite }\end{array}$ & hematite & hematite & hematite \\
\hline
\end{tabular}

Table 4 shows that the solution $\mathrm{pH}$ increases rapidly with the increase of solid/liquor ratio, indicating that the dissolution of serpentine consume large amounts of acid. The solution $\mathrm{pH}$ increased slowly when solid/liquor ratio was $10 \mathrm{~g}$ ore/L leaching agent or above. When solid/liquor ratio was $14 \mathrm{~g}$ ore $/ \mathrm{L}$ leaching agent, there was undissolved serpentine in the leach residues, indicating the too high solid/liquor ratio would result in the incomplete dissolution of serpentine. 
Table 4 Solution $\mathrm{pH}$ and phases of leach residues under different solid/liquor ratios $\left(60 \mathrm{~min}, 70^{\circ} \mathrm{C}\right.$ )

\begin{tabular}{lllllll}
\hline $\begin{array}{l}\text { Solid/liquor ratio } \\
\text { (g ore/L leaching agent) }\end{array}$ & 4 & 6 & 8 & 10 & 12 & 14 \\
\hline $\begin{array}{l}\text { Solution pH after } \\
\text { leaching }\end{array}$ & 1.34 & 1.95 & 2.18 & 2.43 & 2.78 & 2.79 \\
Phases of leach residues & $\begin{array}{l}\text { serpentine, } \\
\text { hematite }\end{array}$ & $\begin{array}{l}\text { serpentine, } \\
\text { hematite }\end{array}$ & hematite & hematite & hematite & $\begin{array}{l}\text { serpentine, } \\
\text { hematite }\end{array}$ \\
\hline
\end{tabular}

Table 5 Solution $\mathrm{pH}$ and phases of leach residues under different leaching times ( solid/liquor ratio: $10 \mathrm{~g}$ ore/L leaching agent, $70^{\circ} \mathrm{C}$ )

\begin{tabular}{|c|c|c|c|c|c|}
\hline Leaching time(min) & 30 & 45 & 60 & 75 & 90 \\
\hline $\begin{array}{l}\text { Solution pH after } \\
\text { leaching } \\
\text { Phases of leach } \\
\text { residues }\end{array}$ & $\begin{array}{l}1.41 \\
\text { serpentine, } \\
\text { hematite }\end{array}$ & $\begin{array}{l}1.79 \\
\text { serpentine, } \\
\text { hematite }\end{array}$ & $\begin{array}{l}2.43 \\
\text { hematite }\end{array}$ & $\begin{array}{l}2.58 \\
\text { hematite }\end{array}$ & $\begin{array}{l}2.57 \\
\text { hematite }\end{array}$ \\
\hline
\end{tabular}

Table 6 Solution $\mathrm{pH}$ and phases of leach residues under different leaching times ( solid/liquor ratio: $14 \mathrm{~g}$ ore/L leaching agent, $70^{\circ} \mathrm{C}$ )

\begin{tabular}{lllllll}
\hline \multicolumn{2}{l}{ Leaching time(min) } & 30 & 45 & 60 & 75 & 90 \\
\hline $\begin{array}{l}\text { Solution } \\
\text { leaching }\end{array}$ & $\begin{array}{l}\text { Phases of leach } \\
\text { residues }\end{array}$ & $\begin{array}{l}1.29 \\
\text { serpentine, } \\
\text { hematite }\end{array}$ & $\begin{array}{l}1.65 \\
\text { serpentine, } \\
\text { hematite }\end{array}$ & $\begin{array}{l}\text { serpentine, } \\
\text { hematite }\end{array}$ & $\begin{array}{l}\text { serpentine, } \\
\text { hematite }\end{array}$ & $\begin{array}{l}\text { serpentine, } \\
\text { hematite }\end{array}$ \\
\hline
\end{tabular}

The solution $\mathrm{pH}$ also increased with the increase of leaching time, and changed little when increasing leaching time to $60 \mathrm{~min}$ or above, as seen in Tables 5 and 6. Serpentine was not present in the leach residues at $60 \mathrm{~min}$ and solid/liquor ratio of $10 \mathrm{~g}$ ore $/ \mathrm{L}$ leaching agent, indicating $60 \mathrm{~min}$ was long enough to completely dissolve serpentine. However, when solid/liquor ratio was $14 \mathrm{~g}$ ore $/ \mathrm{L}$ leaching agent, even if increasing leaching time to greater than $60 \mathrm{~min}$, serpentine was still present. This further proves that the too high amount of ore sample is not beneficial to the leaching of high-magnesium minerals. This is probably because that the high amount of ore sample requires the high amount of acid in the leaching agent, while the acid amount is adequate when increasing solid/liquor to $>10 \mathrm{~g}$ ore/L leaching agent. Apparently, the acidity should be an important effect on the leaching of high-magnesium laterite.

Table 7 Concentrations $(\mathrm{g} / \mathrm{L})$ of metal ions in the liquors after leaching of high-magnesium laterite $\left(70^{\circ} \mathrm{C}, 60 \mathrm{~min}\right)$

\begin{tabular}{ccccccc}
\hline $\begin{array}{l}\text { Solid/liquor ratio } \\
\text { (g ore/L leaching agent) }\end{array}$ & $\mathrm{Ni}^{2+}$ & $\mathrm{Co}^{2+}$ & $\mathrm{Mg}^{2+}$ & $\mathrm{Fe}^{2+}$ & $\mathrm{Fe}^{3+}$ & $\mathrm{Al}^{3+}$ \\
\hline 10 & 1.30 & 0.14 & 2.95 & 3.41 & 1.08 & 0.17 \\
14 & 1.33 & 0.16 & 4.44 & 3.61 & 1.93 & 0.19 \\
\hline
\end{tabular}

By comparing the concentration data in Table 7 and those in the leaching agent, it can be found that the concentrations of nickel, cobalt, magnesium and aluminum ions increase. This is because of the dissolution of the high-magnesium minerals. The values of concentrations of metal ions did not increase obviously, simply because that the volume of filtrate increased. However, the $\mathrm{Fe}^{3+}$ concentration increased little, probably because that the iron minerals such as hematite, magnetite and chromite were hardly dissolved. 


\section{Conclusions}

The high-magnesium laterite can be leached using the leach liquors from pressure leaching of laterite containing high-iron content as the leaching agent. The process can adjust the acidity of the leaching agent and decrease the acid consumption of high-magnesium laterite. When the solid/liquor ratio was $10 \mathrm{~g}$ ore/L leaching agent, leaching time was $60 \mathrm{~min}$ and leaching temperature was $70^{\circ} \mathrm{C}$, the high-magnesium minerals can be dissolved completely, and the solution with pH of 2.5 or above and $\mathrm{Fe}^{3+}$ concentration of $1-2 \mathrm{~g} / \mathrm{L}$ can be obtained, which is suitable for the further goethite process. The iron minerals were undissolved and can be introduced into the pressure leaching process.

\section{Acknowledgements}

This work is financially supported by National Nature Science Foundation of China (No. 51264003) and Natural Science Foundation of Guangxi Province (CN) (No. 2014GXNSFAA118325).

\section{References}

[1] R.G. McDonald and B.I. Whittington: Hydrometallurgy Vol.91 (2008), P.35.

[2]W. Luo, Q. Feng, L. Ou, G. Zhang and Y. Lu: Hydrometallurgy Vol. 96 (2009), P.171.

[3] D.H. Rubisov and V.G. Papangelakis: Hydrometallurgy Vol. 58 (2000), p.89.

[4] X.Y.Guo,W.T. Shi and D.Li: Transaction of nonferrous metals society of China Vol.21 (2011), p.191.

[5] B.I.Whittington, D. Muir: Minerals Processing and Extractive Metallurgy Review Vol.21 (2000), p.527.

[6] P.T. Davey and T.R.Scott: Hydrometallurgy Vol. 2(1976), p.25

[7] M.R.C. Ismael and J.M.R. Carvalho: Minerals Engineering Vol.16 (2003), p.31

[8] Y.Chang, X. Zhai, B.Li and Y.Fu: Hydrometallurgy, Vol.101(2010), p.84. 